\title{
A New Actinomycete Species, Nocardiopsis lucentensis sp. nov.
}

\author{
A. F. YASSIN, ${ }^{1 *}$ E. A. GALINSKI, ${ }^{2}$ A. WOHLFARTH, ${ }^{2}$ K.-D. JAHNKE, ${ }^{3}$ K. P. SCHAAL, ${ }^{1}$ AND H. G. TRÜPER ${ }^{2}$ \\ Institut für Medizinische Mikrobiologie und Immunologie der Universität Bonn, Sigmund-Freud Strasse 25, ${ }^{1}$ \\ and Institut für Mikrobiologie und Biotechnologie der Universität Bonn, ${ }^{2} 5300$ Bonn 1, and Deutsche \\ Sammlung von Mikroorganismen und Zellkulturen GmbH, 3300 Braunschweig, ${ }^{3}$ Germany
}

\begin{abstract}
A new species of the genus Nocardiopsis, for which we propose the name Nocardiopsis lucentensis sp. nov. (type strain, strain DSM 44048), was isolated from a salt marsh soil sample near Alicante, Spain. Whole-cell hydrolysates contain the meso isomer of diaminopimelic acid and no characteristic sugar; thus, the cell wall composition is type III. Menaquinone $\mathrm{MK}-10\left(\mathrm{H}_{8}\right)$ is the major menaquinone, and the phospholipid type is type PIII (phosphatidylcholine present). Spore chains are rectiflexibilis, and in the early stages of sporulation zig-zag-shaped aerial hyphae are observed. This microorganism produces compatible solutes of the ectoine type and is characterized by a yellowish to yellowish brown substrate mycelium and a white aerial mycelium. This organism exhibits only 40 to $50 \%$ DNA relatedness to other Nocardiopsis spp.
\end{abstract}

In 1904 Brocq-Rousseau (4) created the name Streptothrix dassonvillei to designate a strain isolated from mildewed grain. Some years later, Liegard and Landrieu (33) isolated a microorganism from a case of conjunctivitis which they considered to be identical to Streptothrix dassonvillei but which they assigned to the genus Nocardia. Gordon and Horan (18) discovered that the macroscopic appearance and a number of the physiological characteristics of Nocardia dassonvillei were similar to those of Streptomyces griseus. Subsequently, Lechevalier and Lechevalier (30) described the genus Actinomadura to harbor Nocardia madurae (Vincent) Blanchard (the type species), Nocardia pelletieri (Laveran) Pinoy, and Nocardia dassonvillei (Brocq-Rousseau) Liegard and Landrieu. However, striking morphological differences of Actinomadura dassonvillei (e.g., the mode of sporulation of the aerial mycelium, the nature of the substrate mycelium, and the lack of madurose in whole-cell hydrolysates) led Meyer to transfer this species to a new genus, Nocardiopsis, as Nocardiopsis dassonvillei (35). The genus Nocardiopsis was described to comprise strains that exhibit fragmenting substrate and aerial mycelia and have cell wall chemotype III (meso isomer of diaminopimelic acid and no characteristic sugar in whole-cell hydrolysates). An earlier description of the genus included microorganisms with a type PIII phospholipid pattern sensu Lechevalier et al. (32) (phosphatidylcholine as a diagnostic phospholipid), as well as microorganisms with a type PIV phospholipid pattern (glucosamine-containing phospholipid). In recent studies $(20,21,24,28)$, strains which possess type PIV phospholipids, including Nocardiopsis coeruleofusca (41, 42), Nocardiopsis flava (13, 41, 42), Nocardiopsis longispora (41, 42), Nocardiopsis mutabilis (43), Nocardiopsis mutabilis subsp. cryophilus (45), and Nocardiopsis syringae (14), were found to contain rhamnose and large amounts of galactose in whole-cell hydrolysates (the sugar pattern characteristic of the genus Saccharothrix [29]) and therefore were reclassified in the genus Saccharothrix. Another species, Nocardiopsis africana, was found to belong to the genus Microtetraspora (25). Phenetic data indicated that the single remaining species in the genus, Nocardiopsis antarctica (1), is identical to the type strain of Nocardiopsis dassonvillei (36). To maintain the integrity of the genus Nocardiopsis, only those actinomycete isolates should be

\footnotetext{
* Corresponding author.
}

included in the genus which possess meso-diaminopimelic acid as the cell wall diamino acid, have no characteristic sugar in whole-cell hydrolysates and no mycolic acids in whole-cell methanolysates (cell wall chemotype III), have phosphatidylcholine as a characteristic phospholipid (phospholipid type III), have fatty acid profiles which comprise saturated, unsaturated, iso, anteiso, and tuberculostearic acids, have menaquinones with 10 isoprene units with a high degree of hydrogenation as major menaquinones, and have DNAs with $\mathrm{G}+\mathrm{C}$ contents of 60 to $70 \mathrm{~mol} \%$.

In the course of isolation of microorganisms from uncommon ecological niches, some unusual filamentous bacteria were isolated from salt marsh soils collected near Alicante, Spain. These organisms had chemotaxonomic and morphological characteristics which justify their placement in the genus Nocardiopsis. However, the physiological behavior of these microorganisms on different media, their inability to grow in basal International Streptomyces Project (ISP) medium 9 , but only when it was supplemented with 5 to $10 \%$ $\mathrm{NaCl}$, and their formation of aerial hyphae on different ISP media only when they were supplemented with 5 to $10 \%$ $\mathrm{NaCl}$ led us to propose the name Nocardiopsis lucentensis sp. nov. for strain $A_{5-1}$.

\section{MATERIALS AND METHODS}

Bacterial strains and culture conditions. The strains used in this study include Nocardiopsis dassonvillei DSM $43111^{\mathrm{T}}$ (T = type strain) $(2,4,30,33,35)$, Nocardiopsis alborubida DSM $40465^{\mathrm{T}}(12,21)$, Nocardiopsis listeri DSM $40297^{\mathrm{T}}(10$, 21, 48), Nocardiopsis alba subsp. alba DSM 43119 (2, 21, 35 , and Nocardiopsis alba subsp. prasina DSM $43845^{\mathrm{T}}$ (21, 40). Strains $A_{5-1}{ }^{T}$ and $A_{4-2}$ were isolated from a soil sample collected in a salt marsh area near Alicante, Spain. The strains were obtained from plates of mineral salts-starch medium containing the following ingredients: $0.5 \mathrm{~g}$ of $\mathrm{K}_{2} \mathrm{HPO}_{4}, 0.1 \mathrm{~g}$ of $\mathrm{MgSO}_{4} \cdot 7 \mathrm{H}_{2} \mathrm{O}, 3.0 \mathrm{~g}$ of $\mathrm{NH}_{4} \mathrm{HCO}_{3}, 0.05 \mathrm{~g}$ of $\mathrm{CaCl}_{2} \cdot 2 \mathrm{H}_{2} \mathrm{O}, 0.01 \mathrm{~g}$ of $\mathrm{FeSO}_{4} \cdot 7 \mathrm{H}_{2} \mathrm{O}, 100 \mathrm{~g}$ of $\mathrm{NaCl}$, $10.0 \mathrm{~g}$ of starch, and $1,000.0 \mathrm{ml}$ of distilled water ( $\mathrm{pH} \mathrm{7.5)}$. The plates were incubated at $30^{\circ} \mathrm{C}$ for 7 days, and the isolates were then subcultured on the same medium. Stock cultures were grown on inorganic salts-starch agar (ISP medium 4). The other media used in this study were those recommended for use by the ISP (44) and include yeast extract-malt extract agar (ISP medium 2), oatmeal agar (ISP medium 3), and glycerol-asparagine agar (ISP medium 5). 
Morphology and pigmentation. The organism was grown on ISP medium 2 , ISP medium 3 , ISP medium 4 , and ISP medium 5, as described by Shirling and Gottlieb (44), and was examined for pigmentation, aerial mycelium, and other morphological features. Cultures were grown for 4 weeks, and observations were made at weekly intervals. Slide preparations from 4-, 7-, or 14-day-old cultures were examined for the presence of spore chains. Air-dried smears from ISP medium 4 were stained by Gram's method and a modification of the Ziehl-Neelsen method in order to determine the Gram reaction and acid fastness, respectively. The micromorphology was determined with a culture grown at $37^{\circ} \mathrm{C}$ for 10 days on ISP medium 4. Preparations of whole cells were stained with fuchsin and safranin and examined under a light microscope at a magnification of $\times 700$. Electron micrographs were made with a Leitz model MMR 1600 scanning electron microscope. Samples of 14-day-old colonial growth on ISP medium 4 supplemented with $10 \% \mathrm{NaCl}$ were prepared by cutting agar blocks from the growth medium, fixing them with glutaraldehyde, and dehydrating them by using a graded methoxyethanol series and finally $100 \%$ acetone. The dehydrated sections were critical point dried, mounted on aluminum stubs, and then sputter coated with gold-palladium.

Physiological tests. The physiological tests used to characterize strains $\mathrm{A}_{5-1}{ }^{\mathrm{T}}$ and $\mathrm{A}_{4-2}$ were those of Gordon $(15,16)$ and Gordon and Mihm (19). The tests used to determine carbohydrate utilization and the test used to determine melanoid pigments were those of Shirling and Gottlieb (44). Catalase production was tested by mixing 1 loopful of a 1 -week-old culture in glucose-nutrient agar with 1 drop of freshly prepared $5 \%$ hydrogen peroxide. Phosphatase activity was determined by the methods of Kurup and Schmitt (27). The release of $o$-nitrophenol from $o$-nitrophenyl- $\beta$-Dgalactopyranoside and $p$-nitrophenyl- $\beta$-D-glucoside was used to assay $\beta$-galactosidase and $\beta$-glucosidase activities, respectively, by the method of Tsukamura (46). Degradation of elastin was determined by the disappearance of the substrate $(0.3 \%, \mathrm{wt} / \mathrm{vol})$ around the area of growth by using nutrient agar as a basal medium; the preparations were incubated for 10 days. Arbutin degradation was determined by the method of Kurup and Schmitt (27). To determine lysozyme susceptibility, a $0.05 \%$ (wt/vol) solution of lysozyme was sterilized by membrane filtration and added to autoclaved Czapek Dox-yeast extract-Casamino Acid broth (7) to give a final concentration of $0.0025 \%$ (wt/vol). Small tubes of medium with and without lysozyme were inoculated with 1 loopful of an old culture and examined for growth for up to 10 days. Strains which grew in both the control and test media were scored as positive for lysozyme resistance (17). Tolerance to salt was determined by growing the organisms on glucose-nutrient agar plates supplemented with 5 and $10 \%$ $\mathrm{NaCl}$. The susceptibilities of the organisms to various antibiotics were studied on nutrient agar plates containing various concentrations of the drugs. The drugs were aseptically mixed with sterile molten agar, and the preparations were maintained at $45^{\circ} \mathrm{C}$ and poured into plates. After inoculation, the plates were incubated at $37^{\circ} \mathrm{C}$ for 1 week. Growth on the media was compared with growth of a control and was recorded as negative or positive (no growth or growth, respectively). Various concentrations $(0.03$ to $128 \mu \mathrm{g} / \mathrm{ml})$ of penicillin $\mathrm{G}$, neomycin, lincomycin, gentamicin, rifampin, and streptomycin were tested.

Cell chemistry. Analysis of whole-cell hydrolysates for characterization of amino acids and sugars was performed by the methods of Becker et al. (3) and Lechevalier (31).
Cellular fatty acid and mycolic acid methyl esters were prepared from whole-cell methanolysates by the method of Minnikin et al. $(37,38)$; the presence of both fatty acid and mycolic acid methyl esters was detected by thin-layer chromatography, and the fatty acid methyl ester profile was determined by gas-liquid chromatography. Menaquinones were extracted and purified by the methods of Collins et al. (6), and menaquinone composition was determined by using a Finnigan Mat 212 mass spectrometer. Phospholipids were extracted by the method of Minnikin et al. (39) and were determined by two-dimensional thin-layer chromatography, using chloroform-methanol-water $(65: 25: 4, \mathrm{vol} / \mathrm{vol})$ in the first dimension followed by chloroform-acetic acid-methanol-water $(40: 7.5: 6: 2, \mathrm{vol} / \mathrm{vol})$ in the second dimension. The phospholipids were visualized by spraying the preparation with the phosphate stain of Dittmer and Lester (9) and were tentatively identified by using phospholipid standards. Phosphatidylcholine was identified with Dragendorf's reagent (47).

DNA isolation and characterization. DNA was isolated by chromatography on hydroxyapatite by using the method of Cashion et al. (5). The $\mathrm{G}+\mathrm{C}$ contents were determined by high-performance liquid chromatography (34). DNA-DNA hybridizations were carried out by using the method of De Ley et al. (8) as modified by Huss et al. (22). The concentration of DNA was $45 \mu \mathrm{g} / \mathrm{ml}$. Because of the high $\mathrm{G}+\mathrm{C}$ content of the DNAs, $20 \%$ (vol/vol) dimethyl sulfoxide (11) was added to $2.5 \times$ standard saline citrate $(1 \times$ standard saline citrate is $0.15 \mathrm{M} \mathrm{NaCl}$ plus $0.015 \mathrm{M}$ sodium citrate) to depress the melting point $\left(T_{m}\right)$ of the DNA. The resulting buffer contained $2 \times$ standard saline citrate and $20 \%$ dimethyl sulfoxide. The average $T_{m}$ was determined from the DNA melting curves, and the optimal temperature of renaturation (TOR) was calculated as follows: $\mathrm{TOR}=T_{m}-25^{\circ} \mathrm{C}$. Levels of DNA-DNA relatedness were determined from the renaturation rates, which were calculated by regression analysis of data obtained between 10 and 30 min after the start of the reaction, using the computer program TRANSFER.BAS (23). The DNA relatedness values $(H)$ were calculated by the following formula: $H=[(4 \times \mathrm{VM})-\mathrm{VA}-\mathrm{VB}] /(2 \times \sqrt{ } \mathrm{VA}$ $\times V B$ ), where $V$ is the renaturation rate, $A$ is $D_{N A}, B$ is $\mathrm{DNA}_{b}$, and $\mathrm{M}$ is a $1: 1$ mixture of $\mathrm{DNA}_{a}$ and $\mathrm{DNA}_{\mathrm{b}}$.

\section{RESULTS AND DISCUSSION}

Strain $\mathrm{A}_{5-1}{ }^{\mathrm{T}}$ has microbiological properties consistent with its assignment to the genus Nocardiopsis $(35,36)$. It is an aerobic, gram-positive, non-acid-fast, nonmotile organism which forms an extremely branched substrate mycelium that fragments into rod and coccal elements. The substrate mycelium bears the aerial hyphae, which frequently form chains of smooth spores (Fig. 1). During spore formation hyphae have a zig-zag appearance because of developing spore subtending angles of various degrees with respect to the neighboring spores.

Strain $\mathrm{A}_{5-1}{ }^{\mathrm{T}}$ has chemotaxonomic characteristics which support its placement in the genus Nocardiopsis. The cell wall contains meso-diaminopimelic acid as the diamino acid and possesses no characteristic sugars (wall chemotype III); the organism lacks mycolic acids, contains major amounts of iso and anteiso branched-chain fatty acids, as well as substantial amounts of tuberculostearic acid, has menaquinones with 10 isoprene units, with the octahydrogenated form MK-10 $\left(\mathrm{H}_{8}\right)$ as the major menaquinone, and has phospholipid type PIII sensu Lechevalier et al. (32) (phosphatidylcholine as the characteristic phospholipid). 


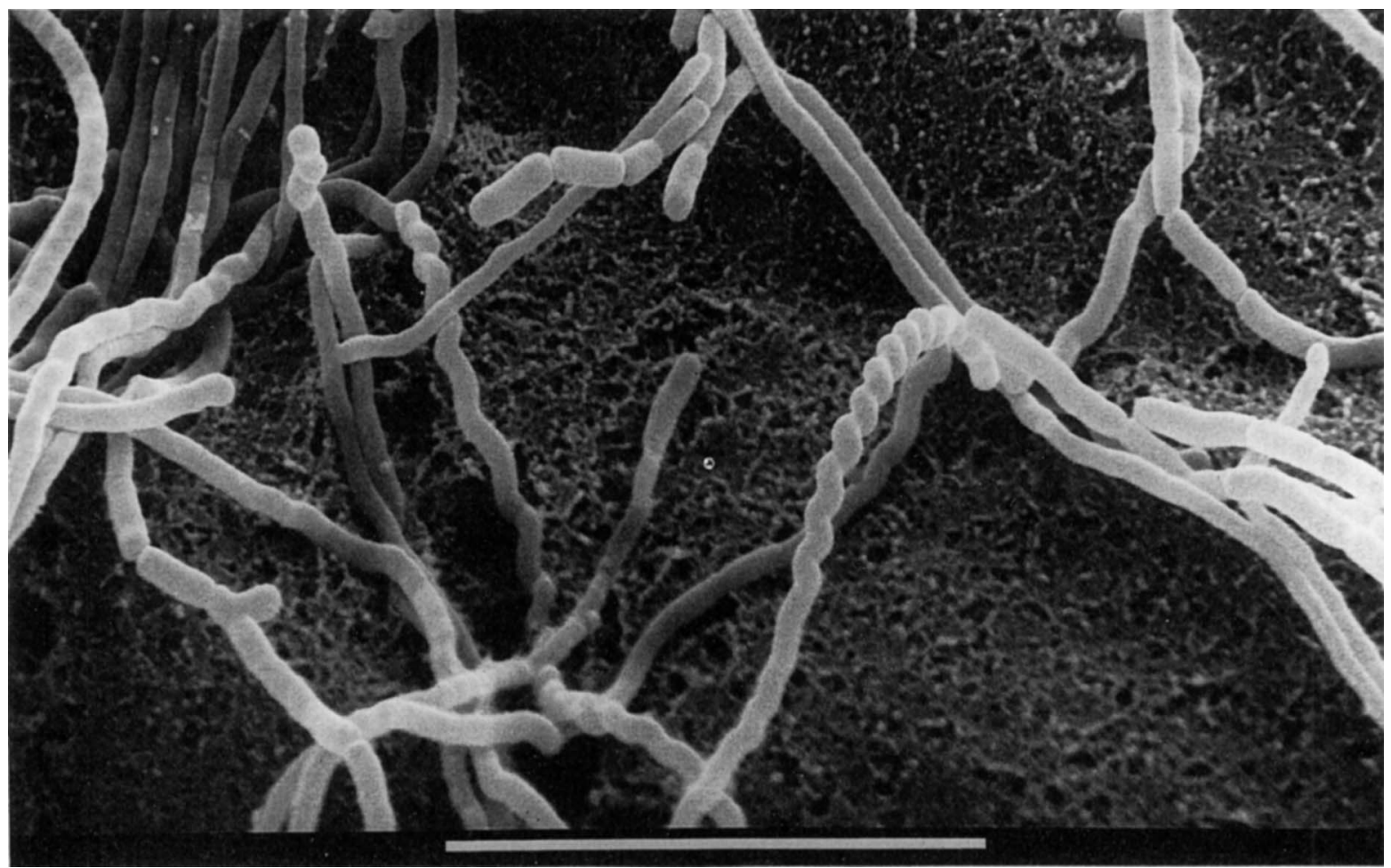

FIG. 1. Scanning electron micrograph of strain $\mathrm{A}_{5-1}{ }^{\mathrm{T}}$, showing zig-zag hyphae and spore chain with a smooth surface. The culture was grown on ISP medium 4 supplemented with $10 \% \mathrm{NaCl}$ for 14 days at $35^{\circ} \mathrm{C}$. Bar $=1.0 \mu \mathrm{m}$.

Identity of species. A total of five strains of Nocardiopsis spp. were grown along with strain $\mathrm{A}_{5-1}^{\mathrm{T}}$ on different media to study 56 physiological characteristics (Tables 1 and 2). Although these strains share many characteristics, they can be separated into two groups on the basis of the ability to grow in ISP medium 9 and utilize different carbon sources. The first group includes strain $\mathrm{A}_{5-1}^{\mathrm{T}}$, Nocardiopsis alborubida DSM $40465^{\mathrm{T}}$, Nocardiopsis listeri DSM $40297^{\mathrm{T}}$, and Nocardiopsis alba subsp. prasina DSM $43845^{\mathrm{T}}$, which were not able to grow in ISP medium 9 and to utilize carbon sources unless the medium was supplemented with $5 \% \mathrm{NaCl}$ (Table 2). The second group includes Nocardiopsis dassonvillei DSM $43111^{\mathrm{T}}$ and Nocardiopsis alba subsp. alba DSM 43119 , which were able to grow and to utilize carbon sources in the presence or absence of $\mathrm{NaCl}$ (Table 2). Tables 1 and 2 list the differences between strain $\mathrm{A}_{5-1}{ }^{\mathrm{T}}$ and other members of the two groups.

The $\mathrm{G}+\mathrm{C}$ content of the DNA of strain $\mathrm{A}_{5-1}{ }^{\mathrm{T}}$ was 71.0 mol\%. Table 3 shows the levels of DNA relatedness between strain $A_{5-1} T$ and the other strains, as determined by the optical method. The DNA of strain $\mathrm{A}_{5-1}{ }^{\mathrm{T}}$ exhibits levels of relatedness ranging from 40 to $50 \%$ with the DNAs of other Nocardiopsis species. These values indicate the homogeneity of the genus Nocardiopsis. This is in contrast to the previous description of Meyer (36), which was based on an old description of the genus.

Together, these differences suggest that strain $A_{5-1}{ }^{T}$ is unlikely to be a previously described Nocardiopsis species. Thus, we propose for it the name Nocardiopsis lucentensis. A description is given below.

Nocardiopsis lucentensis sp. nov. Nocardiopsis lucentensis (lu. cen. ten'sis. M. L. adj. lucentensis, referring to Lucentum, the ancient Latin name of Alicante, a city in Spain, where the type strain was isolated). Aerobic, gram-positive, non-acid-fast, nonmotile, filamentous actinomycete.

Cultural characteristics. Cultures of strain $A_{5-1}^{\mathrm{T}}$ grow well on both complex and defined media. Aerial hyphae are initiated when $\mathrm{NaCl}$ at a concentration of up to $10 \%$ is added to the growth medium. The aerial spore mass color is predominantly white. The reverse side of culture growth is yellow to yellowish brown. No distinctive pigmentation is present.

Morphological characteristics. (i) Aerial mycelium. On ISP medium 2, ISP medium 3, and ISP medium 4, all supplemented with 5 to $10 \% \mathrm{NaCl}$, well-developed branched aerial hyphae are present. The aerial hyphae are white, long, and at the beginning of sporulation more or less zig-zag shaped (Fig. 1). The zig-zag-shaped hyphae subdivide into smaller spores (Fig. 1). Spores are elongated and have smooth surfaces (Fig. 1).

(ii) Substrate mycelium. Strain $\mathrm{A}_{5-1}{ }^{\mathrm{T}}$ produces an extensive substrate mycelium that fragments. It first appears to be yellowish and then becomes yellowish brown on ISP medium 2, ISP medium 3, and ISP medium 4.

Physiological characteristics. Strain $\mathrm{A}_{5-1}{ }^{\mathrm{T}}$ produces acid from the following carbohydrates: glucose, inositol, mannitol, raffinose, and rhamnose. Acid is not produced from adonitol, dulcitol, erythritol, lactose, melibiose, $\alpha$-methyl-Dglucoside, glucitol, and xylose.

Growth does not occur in ISP medium 9 supplemented with different carbon sources. However, growth occurs in ISP medium 9 which is supplemented with 5 to $10 \% \mathrm{NaCl}$ and contains mannose, glucose, rhamnose, maltose, mannitol, D-fructose, sucrose, raffinose, glycerol, trehalose, and myo-inositol as sole sources of carbon but not in medium containing L-arabinose, D-xylose, D-galactose, and lactose. 
TABLE 1. Differential physiological characteristics of strain $\mathrm{A}_{5-1}$ and other Nocardiopsis species

\begin{tabular}{|c|c|c|c|c|c|c|}
\hline Characteristic & Strain $A_{5-1}{ }^{T}$ & 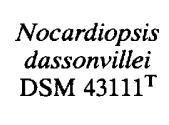 & $\begin{array}{c}\text { Nocardiopsis } \\
\text { alborubida } \\
\text { DSM } 40465^{\mathrm{T}}\end{array}$ & $\begin{array}{c}\text { Nocardiopsis } \\
\quad \text { listeri } \\
\text { DSM } 40297^{\mathrm{T}}\end{array}$ & $\begin{array}{c}\text { Nocardiopsis } \\
\text { alba subsp. } \\
\text { alba } \\
\text { DSM } 43119\end{array}$ & $\begin{array}{l}\text { Nocardiopsis } \\
\text { alba subsp. } \\
\text { prasina } \\
\text { DSM 43845 }\end{array}$ \\
\hline \multicolumn{7}{|l|}{ Decomposition of: } \\
\hline Adenine & + & $\mathrm{ND}^{a}$ & + & + & + & + \\
\hline Hypoxanthine & + & + & + & + & + & + \\
\hline Tyrosine & + & + & + & + & + & + \\
\hline Xanthine & + & + & + & + & + & + \\
\hline Casein & + & + & + & + & + & ND \\
\hline Urea & - & - & - & - & + & - \\
\hline Allantoin & - & - & - & - & + & - \\
\hline \multicolumn{7}{|l|}{ Hydrolysis of: } \\
\hline Starch & + & ND & + & + & + & + \\
\hline Esculin & + & + & + & - & + & - \\
\hline Gelatin & + & - & + & + & + & + \\
\hline Elastin & ND & + & + & + & + & + \\
\hline Arbutin & - & + & - & - & - & - \\
\hline \multicolumn{7}{|l|}{ Decarboxylation of: } \\
\hline Citrate & + & + & + & + & + & + \\
\hline Malate & + & + & + & + & + & + \\
\hline Succinate & + & + & + & + & + & + \\
\hline Acetate & + & + & + & + & + & + \\
\hline Pyruvate & + & + & + & + & + & + \\
\hline Propionate & + & - & + & + & + & + \\
\hline Lactate & - & - & + & + & + & + \\
\hline Oxalate & - & - & + & - & - & + \\
\hline \multicolumn{7}{|l|}{ Acid production from: } \\
\hline Adonitol & - & - & - & - & - & - \\
\hline Dulcitol & - & - & - & - & - & - \\
\hline Erythritol & - & - & - & - & - & - \\
\hline Glucose & + & + & + & - & + & + \\
\hline Inositol & + & - & - & - & - & - \\
\hline Lactose & - & - & - & - & - & - \\
\hline Mannitol & + & - & + & - & - & + \\
\hline Melibiose & - & - & - & - & - & - \\
\hline$\alpha$-Methyl-D-glucoside & - & - & - & - & - & - \\
\hline Raffinose & + & - & - & - & - & - \\
\hline Rhamnose & + & + & + & + & - & - \\
\hline Sorbitol & - & - & - & - & - & - \\
\hline Xylose & - & + & + & + & + & + \\
\hline Resistance to lysozyme & - & - & - & - & - & - \\
\hline \multicolumn{7}{|l|}{ Production of: } \\
\hline Phosphatase & + & + & + & + & + & + \\
\hline$\beta$-Galactosidase & - & + & + & + & + & + \\
\hline$\beta$-Glucosidase & - & + & + & + & + & + \\
\hline \multicolumn{7}{|l|}{ Growth in the presence of: } \\
\hline $5.0 \% \mathrm{NaCl}$ & + & + & + & + & + & + \\
\hline $10.0 \% \mathrm{NaCl}$ & + & - & - & - & + & + \\
\hline
\end{tabular}

${ }^{a} \mathrm{ND}$, not determined.

Citrate, malate, succinate, acetate, pyruvate, and propionate are decarboxylated, but lactate and oxalate are not. Strain $\mathrm{A}_{5-1}{ }^{\mathrm{T}}$ decomposes adenine, hypoxanthine, tyrosine, and xanthine and hydrolyzes casein, starch, gelatin, and esculin but not urea, allantoin, and arbutin. It produces catalase and phosphatase but neither $\beta$-galactosidase nor $\beta$-glucosidase. Melanin pigments are not produced on either ISP medium 6 or ISP medium 7. The organism reduces nitrates to nitrites.

Strain $A_{5-1}{ }^{T}$ is resistant to lincomycin $(128 \mu \mathrm{g} / \mathrm{ml})$, penicillin $\mathrm{G}(128 \mu \mathrm{g} / \mathrm{ml})$, gentamicin $(64 \mu \mathrm{g} / \mathrm{ml})$, streptomycin $(64$ $\mu \mathrm{g} / \mathrm{ml})$, and neomycin $(4 \mu \mathrm{g} / \mathrm{ml})$ but not rifampin $(128 \mu \mathrm{g} / \mathrm{ml})$. The organism is susceptible to lysozyme and tolerates $\mathrm{NaCl}$ at levels up to and including $10 \%$.

Chemotaxonomy. Hydrolyzed whole cells contain mesodiaminopimelic acid. Glucose and arabinose are detected in whole-cell extracts. Thus, strain $\mathrm{A}_{5-1}{ }^{\mathrm{T}}$ has a type III cell wall and a variant of the type $C$ sugar pattern. Mycolic acids are not detected. Phospholipid determinations performed with whole cells indicate that phosphatidylcholine, phosphatidylmethylethanolamine, phosphatidylglycerol, and diphos- 
TABLE 2. Carbon assimilation by strain $\mathrm{A}_{5-1}{ }^{\mathrm{T}}$ and other Nocardiopsis spp. on ISP medium 9 supplemented with $5 \% \mathrm{NaCl}$

\begin{tabular}{|c|c|c|c|c|c|c|}
\hline $\begin{array}{l}\text { Carbon } \\
\text { source }\end{array}$ & Strain $A_{5-1}{ }^{T}$ & $\begin{array}{l}\text { Nocardiopsis alba } \\
\text { subsp. prasina } \\
\text { DSM } 43845^{\mathrm{T}}\end{array}$ & $\begin{array}{l}\text { Nocardiopsis } \\
\text { alborubida } \\
\text { DSM } 40465^{\mathrm{T}}\end{array}$ & $\begin{array}{l}\text { Nocardiopsis } \\
\quad{ }^{\text {listeri }} \\
\text { DSM } 40297^{\mathrm{T}}\end{array}$ & 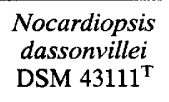 & $\begin{array}{l}\text { Nocardiopsis alba } \\
\text { subsp. alba } \\
\text { DSM } 43119\end{array}$ \\
\hline L-Arabinose & - & + & + & + & - & - \\
\hline D-Xylose & - & + & + & - & + & - \\
\hline D-Mannose & + & + & + & + & + & + \\
\hline D-Glucose & + & + & + & + & + & + \\
\hline L-Rhamnose & + & - & + & + & + & - \\
\hline D-Mannitol & + & + & + & + & + & + \\
\hline D-Fructose & + & + & + & - & + & + \\
\hline D-Galactose & - & + & + & + & + & - \\
\hline Maltose & + & + & + & + & + & + \\
\hline Sucrose & + & + & + & - & + & + \\
\hline Lactose & - & + & - & - & - & - \\
\hline Raffinose & + & - & - & - & - & - \\
\hline Glycerol & + & + & + & - & + & + \\
\hline Trehalose & + & + & + & - & - & + \\
\hline myo-Inositol & + & - & - & - & - & - \\
\hline
\end{tabular}

phatidylglycerol are present. Therefore, strain $\mathrm{A}_{5-1}{ }^{\mathrm{T}}$ has a type PIII phospholipid pattern. The menaquinones detected in strain $\mathrm{A}_{5-1}$ are octahydrogenated menaquinones with 10 isoprene units [MK-10 $\left.\left(\mathrm{H}_{8}\right)\right]$. Minor amounts of tetra-, hexa-, and decahydrogenated menaquinones with 10 isoprene units [MK-10 $\left(\mathrm{H}_{4}\right)$, MK-10 $\left(\mathrm{H}_{6}\right)$, MK-10 $\left.\left(\mathrm{H}_{10}\right)\right]$, as well as tetra-, hexa-, octa-, and decahydrogenated menaquinones with nine isoprene units $\left[\mathrm{MK}-9\left(\mathrm{H}_{4}\right), \mathrm{MK}-9\left(\mathrm{H}_{6}\right), \mathrm{MK}-9\left(\mathrm{H}_{8}\right)\right.$, MK$9\left(\mathrm{H}_{10}\right)$ ], are also present. The fatty acid profile of strain $\mathrm{A}_{5-1} \mathrm{~T}$ consists of major amounts of saturated branched-chain fatty acids of the iso and anteiso types (iso- $\mathrm{C}_{16: 0}, 32 \%$; anteiso$\mathrm{C}_{17: 0}, 14.5 \%$; iso- $\left.\mathrm{C}_{18: 0}, 9.4 \%\right)$, straight-chain saturated fatty acids $\left(n-\mathrm{C}_{16: 0}, 3.9 \% ; n-\mathrm{C}_{17: 0}, 1.5 \% ; n-\mathrm{C}_{18: 0}, 9.9 \%\right)$, and 10-methyl branched-chain fatty acids represented by tuberculostearic acid (10-methyl $\left.\mathrm{C}_{18: 0}, 15.4 \%\right)$.

DNA-DNA hybridization. The renaturation rates as determined by the optical method reveal binding values that range from 40 to $46 \%$ between strain $\mathrm{A}_{5-1}^{\mathrm{T}}$ and the other Nocardiopsis species (Table 3).

Type strain. The type strain is strain $\mathrm{A}_{5-1}$ (= DSM 44048). It was isolated from soil collected in Alicante, Spain. The species description is based on a single strain and thus serves as the type strain description.

Another variant, strain $A_{4-2}$, which was found to be phenotypically identical to $A_{5-1}$, exhibited a DNA relatedness level of $39 \%$ to $A_{5-1}{ }^{T}$ (Table 3). However, we hesitate to suggest a new species for this strain because it is recommended that "a distinct genospecies that cannot be differentiated from another genospecies on the basis of any known

TABLE 3. Degrees of DNA binding between $A_{5-1}{ }^{T}$ and other Nocardiopsis species

\begin{tabular}{lcc}
\hline \multirow{2}{*}{ Organism } & \multicolumn{2}{c}{ Degree of binding (\%) to: } \\
\cline { 2 - 3 } & $\mathrm{A}_{5-1}{ }^{\mathrm{T}}$ & $\mathrm{A}_{4-2}$ \\
\hline $\mathrm{A}_{5-1} \mathrm{~T}$ & 100 & $39 \pm 3^{a}$ \\
$\mathrm{~A}_{4-2}$ & $39 \pm 3$ & 100 \\
Nocardiopsis dassonvillei & $44 \pm 1$ & $65 \pm 4$ \\
Nocardiopsis alborubida & $40 \pm 1$ & $63 \pm 1$ \\
Nocardiopsis listeri & 46 & $34 \pm 1$ \\
Nocardiopsis alba subsp. alba & 41 & $31 \pm 1$ \\
Nocardiopsis alba subsp. prasina & $42 \pm 1$ & $44 \pm 1$ \\
\hline
\end{tabular}

${ }^{a}$ Mean \pm standard deviation. phenotypic property shall not be named until they can be differentiated by some phenotypic property" (49).

\section{ACKNOWLEDGMENTS}

We thank G. Tuschewitzky (Hygiene Institut Bonn) for preparing the electron micrograph. E.A.G. thanks G. Vobis (Hoechst A.G.) for helpful advice during this study.

\section{REFERENCES}

1. Abyzov, S. S., S. N. Philipova, and V. D. Kuznetsov. 1983. Nocardiopsis antarcticus, a new species of actinomycetes, isolated from the ice sheet of the central antarctic glacier. Izv. Akad. Nauk SSSR Ser. Biol. 4:559-568.

2. Athalye, A., M. Goodfellow, J. Lacey, and R. P. White. 1984. Numerical classification of Actinomadura and Nocardiopsis. Int. J. Syst. Bacteriol. 35:86-98.

3. Becker, B., M. P. Lechevalier, R. E. Gorden, and H. A. Lechevalier. 1964. Rapid differentiation between Nocardia and Streptomyces by paper chromatography of whole cell hydrolysates. Appl. Microbiol. 12:421-423.

4. Brocq-Rousseau, D. 1904. Sur un Streptothrix. Rev. Bot. 16: 219-230.

5. Cashion, P., M. A. Holder-Franklin, J. McCully, and M. Franklin. 1977. A rapid method for the base ratio determination of bacterial DNA. Anal. Biochem. 81:461-466.

6. Collins, M. D., T. Pirouz, M. Goodfellow, and D. E. Minnikin. 1977. Distribution of menaquinones in actinomycetes and corynebacteria. J. Gen. Microbiol. 100:221-230.

7. Cross, T., and R. W. Attwell. 1974. Recovery of viable thermoactinomycete endospores from deep mud cores, p. 11-20. In A. N. Barker, G. W. Gould, and J. Wolf (ed.), Spore research. Academic Press, London.

8. De Ley, J., H. Cattoir, and A. Reynaerts. 1970. The quantitative measurement of DNA hybridization from renaturation rates. Eur. J. Biochem. 12:133-142.

9. Dittmer, J. C. F., and R. L. Lester. 1964. A simple specific spray for the detection of phospholipids on thin-layer chromatograms. J. Lipid Res. 5:126-127.

10. Erikson, D. 1935. The pathogenic aerobic organisms of the Actinomyces group. Med. Res. Counc. (G.B.) Spec. Rep. Ser. 203:1-61.

11. Escara, J. F., and J. R. Hutton. 1980. Thermal stability and renaturation of DNA in dimethyl sulfoxide solutions: acceleration of the renaturation rate. Biopolymers 19:1315-1327.

12. Gauze, G. F., T. P. Preobrazhenskaya, E. S. Kudrina, N. O. Blinov, I. D. Ryabova, and M. A. Sveshnikova (ed.). 1957. Problems of classification of actinomycetes-antagonists. Government Publishing House of Medical Literature, Moscow. 
13. Gauze, G. F., T. S. Maksimova, O. L. Olkhovatova, M. A. Sveshnikova, G. V. Kochetkova, and G. B. Ilchemko. 1974. Production of madumycin, an antibacterial antibiotic, by Actinomadura flava sp. nov. Antibiotiki (Moscow) 9:771-775.

14. Gauze, G. F., G. V. Sveshnikova, R. S. Ukholina, G. N. Komorova, and V. S. Bashanov. 1977. Production of nocamycin, a new antibiotic, by Nocardiopsis syringae sp. nov. Antibiotiki (Moscow) 22:483-486.

15. Gordon, R. E. 1966. Some criteria for the recognition of Nocardia madurae (Vincent) Blanchard. J. Gen. Microbiol. 45:355-364.

16. Gordon, R. E. 1967. The taxonomy of soil bacteria, p. 239-321. In T. R. G. Gray and D. Parkinson (ed.), The ecology of soil bacteria. Liverpool University Press, Liverpool, United Kingdom.

17. Gordon, R. E., and D. A. Barnett. 1977. Resistance to rifampin and lysozyme of strains of some species of Mycobacterium and Nocardia as a taxonomic tool. Int. J. Syst. Bacteriol. 27:176178.

18. Gordon, R. E., and A. C. Horan. 1968. Nocardia dassonvillei, a macroscopic replica of Streptomyces griseus. J. Gen. Microbiol. 50:235-240.

19. Gordon, R. E., and J. M. Mihm. 1962. The type species of the genus Nocardia. J. Gen. Microbiol. 27:1-10.

20. Grund, E., and R. M. Kroppenstedt. 1989. Transfer of five Nocardiopsis species to the genus Saccharothrix Labeda et al. 1984. Syst. Appl. Microbiol. 12:267-274.

21. Grund, E., and R. M. Kroppenstedt. 1990. Chemotaxonomy and numerical taxonomy of the genus Nocardiopsis Meyer 1976. Int. J. Syst. Bacteriol. 40:5-11.

22. Huss, V. A. R., H. Festl, and K. H. Schleifer. 1983. Studies on the spectrophotometric determination of DNA hybridization from renaturation rates. Syst. Appl. Microbiol. 4:184-192.

23. Jahnke, K.-D. 1992. Basic computer program for evaluation of spectroscopic DNA renaturation data from GILFORD SYSTEM 2600 spectrophotometer on a PC/XT/AT type personal computer. J. Microbiol. Methods 15:61-73.

24. Kroppenstedt, R. M. 1992. The genus Nocardiopsis, p. 11391156. In A. Balows, H. G. Trüper, M. Dworkin, W. Harder, and K. H. Schleifer (ed.), The prokaryotes, 2nd ed. Springer Verlag, New York.

25. Kroppenstedt, R. M., E. Stackebrandt, and M. Goodfellow. 1990. Taxonomic revision of the actinomycete genera Actinomadura and Microtetraspora. J. Syst. Appl. Bacteriol. Microbiol. 13:184-160.

26. Kurup, V. P., and J. N. Fink. 1975. A scheme for the identification of thermophilic actinomycetes associated with hypersensitivity pneumonitis. J. Clin. Microbiol. 2:55-61.

27. Kurup, V. P., and J. A. Schmitt. 1973. Numerical taxonomy of Nocardia. Can. J. Microbiol. 19:1035-1048.

28. Labeda, D. P., and M. P. Lechevalier. 1989. Amendment of the genus Saccharothrix Labeda et al. 1984 and descriptions of Saccharothrix espanaensis sp. nov., Saccharothrix cryophilis sp. nov., and Saccharothrix mutabilis comb. nov. Int. J. Syst. Bacteriol. 39:420-423.

29. Labeda, D. P., R. T. Testa, M. P. Lechevalier, and H. A. Lechevalier. 1984. Saccharothrix, a new genus of the Actinomycetales related to Nocardiopsis. Int. J. Syst. Bacteriol. 34:426431.

30. Lechevalier, H. A., and M. P. Lechevalier. 1970. A critical evaluation of the genera of aerobic actinomycetes, p. 393-405. In $\mathrm{H}$. Prauser (ed.), The Actinomycetales. VEB Gustav Fischer Verlag, Jena, Germany.

31. Lechevalier, M. P. 1968. Identification of aerobic actinomycetes of clinical importance. J. Lab. Clin. Med. 71:934-944.

32. Lechevalier, M. P., C. de Bievere, and H. A. Lechevalier. 1977. Chemotaxonomy of aerobic actinomycetes: phospholipid composition. Biochem. Syst. Ecol. 5:249-260.

33. Liegard, H., and M. Landrieu. 1911. Un cas de mycose conjunctivale. Ann. Ocul. 146:418-426.

34. Mesbah, M., U. Premachandran, and W. B. Whitman. 1989. Precise measurement of the $\mathrm{G}+\mathrm{C}$ content of deoxyribonucleic acid by high-performance liquid chromatography. Int. J. Syst. Bacteriol. 39:159-167.

35. Meyer, J. 1976. Nocardiopsis, a new genus of the order Actinomycetales. Int. J. Syst. Bacteriol. 26:487-493.

36. Meyer, J. 1989. Genus Nocardiopsis 1976, p. 2562-2569. In S. T. Williams, M. E. Sharpe, and J. G. Holt (ed.), Bergey's manual of systematic bacteriology, vol. 4. Williams and Wilkins, Baltimore.

37. Minnikin, D. E., L. Alshamaony, and M. Goodfellow. 1975. Differentiation of Mycobacterium, Nocardia and related taxa by thin-layer chromatographic analysis of whole-cell methanolysates. J. Gen. Microbiol. 88:200-204.

38. Minnikin, D. E., I. G. Hutchinson, A. B. Caldicott, and M. Goodfellow. 1980. Thin-layer chromatography of methanolysates of mycolic acid-containing bacteria. J. Gen. Chromatogr. 188:221-233.

39. Minnikin, D. E., A. G. O'Donell, M. Goodfellow, G. Alderson, M. Athalye, A. Schaal, and J. H. Parlett. 1984. An integrated procedure for the extraction of isoprenoid quinones and polar lipids. J. Microbiol. Methods 2:233-241.

40. Miyashita, M., Y. Mikami, and T. Arai. 1984. Alkalophilic actinomycete, Nocardiopsis dassonvillei subsp. prasina subsp. nov., isolated from soil. Int. J. Syst. Bacteriol. 34:405-409.

41. Preobrazhenskaya, T. P., and M. A. Sveshnikova. 1974. New species of the genus Actinomadura. Mikrobiologiya 43:864-868.

42. Preobrazhenskaya, T. P., M. A. Sveshnikova, and G. F. Gauze. 1982. On the transfer of certain species of the genus Actinomadura Lechevalier et Lechevalier 1970 to the genus Nocardiopsis Meyer 1976. Mikrobiologiya 51:111-113.

43. Shearer, M. C., P. M. Colman, and C. H. Nash III. 1983. Nocardiopsis mutabilis, a new species of nocardioform bacteria isolated from soil. Int. J. Syst. Bacteriol. 33:369-374.

44. Shirling, E. B., and D. Gottlieb. 1966. Methods for characterization of Streptomyces species. Int. J. Syst. Bacteriol. 16:313340.

45. Takahashi, A., K. Hotta, N. Saito, M. Morioka, Y. Okami, and H. Umezawa. 1986. Production of novel antibiotic, dopsisamine, by a new subspecies of Nocardiopsis mutabilis with multiple antibiotic resistance. J. Antibiot. 39:175-183.

46. Tsukamura, M. 1974. Differentiation of the "Mycobacterium" rhodochrous group from Nocardia by $\beta$-galactosidase activity. J. Gen. Microbiol. 80:553-555.

47. Wagner, H., L. Horhammer, and L. Wollf. 1961. Dünnschichtchromatographie von Phosphatiden und Glycolipiden. Biochem. Z. 334:175-184.

48. Waksman, S. A., and A. T. Henrici. 1948. Family Actinomycetaceae Buchanan and family Streptomycetaceae Waksman and Henrici, p. 961. In R. S. Breed, E. G. D. Murray, and A. P. Hitchens (ed.), Bergey's manual of determinative bacteriology, 6th ed. The Williams and Willkins Co., Baltimore.

49. Wayne, L. G., D. J. Brenner, R. R. Colwell, P. A. D. Grimont, O. Kandler, M. I. Krichevsky, L. H. Moore, W. E. C. Moore, R. G. E. Murray, E. Stackebrandt, M. P. Starr, and H. G. Trüper. 1987. Report of the Ad Hoc Committee on Reconciliation of Approaches to Bacterial Systematics. Int. J. Syst. Bacteriol. 37:463-464. 